\title{
Effect of Organic Fertilizers, Irrigation Regimes and Biological Amendments on Growth and Production of Sweet Pepper
}

\author{
E. M. El-Said \\ Vegetable Research Department, Horticulture Research \\ Institute, Agricultural Research Centre,Cairo, Egypt.
}

\begin{abstract}
RGANIC fertilizer regimes consisting of combinations of compost, liquid fertilizers and conventional fertilizer with or without biological amendments (Rhizosphere bacteria and vascular arbuscular mycorrhiza, VAM) were evaluated under three irrigation regimes $(60,80$ and $100 \%$ of evapo-transpirantsio, ET) in two experiments with open field pepper grown in peat-based substrate. Therefore, field experiments were conducted at private farm, near Mansoura City, Dakahlia Governorate, Egypt, during summer seasons of 2012 and 2013. The irrigation regime treatments were randomly distributed among the main plots, organic fertilizer treatments arranged among the sub plots, while biological amendment treatments were allocated as sub-sub plots.
\end{abstract}

The combined interaction of irrigation at $80 \%$ of ET and conventional fertilizer with microbial soil amendments had significant effects on vegetative growth characters (dry weight) and chemical composition (N, P and K content) of sweet pepper plants. This treatment led to the significant increase in early and total yield of sweet pepper plants and the highest significant values of fruit quality (fruit flesh thickness, acidity, T.S.S. \% and vitamin C). The combined interactions recommended doses of mineral fertilizers, irrigation regime and VAM with rhizosphere bacteria gave the highest significant increase in early and total yields.

Organic fertilizer, irrigation water regimes and microbial inoculation, either separately or in different interactions had significant effects in in pepper's early yield, total yield, total number of fruits per plot, fruit flesh thickness and quality parameters.

Keywords: Organic, Irrigation, Mycorrhiza, Biological, Sweet pepper.

Organic production methods encourage the use of organic waste materials as substitutes for chemical fertilizers. This may be an effective way to use the high volumes of urban yard waste and waste organic materials emanating from dairy, poultry, sheep, or greenhouse operations and is therefore of potentially significant environmental value (Cheng et al., 2004 and Mazuela et al., 2005). Chong and Purvis (2004) and Chong (2005) had developed recommendations for the use of a variety of waste and compost products in the nursery industry, some of which could be applied to organic production settings. Amending soil or potting media with some 
organic wastes can improve soil physical properties with increased porosity and water holding capacity as well as improved biological characteristics (Marinari et al., 2000, Celik et al., 2004 and Lee et al., 2004).

A full range of organic wastes, from municipal wastes to agricultural residues, could potentially be used as compost feedstock, depending on local availability and country legislation for organic products. For example, composts produced from different types of agricultural residues may be are suitable materials for container media or in field soils (Martı'nez et al., 2005). Rippy et al. (2004) found that several combinations of vermicompost plus organic liquid feeds produced yields similar to those of conventional hydroponic treatments.

Liquid fertilizers formulated for organic agriculture are often made from organic wastes and can be applied as a foliar spray or through drip irrigation lines as an alternative to chemical fertilizer. Cheng et al. (2004) used a greenhouse tomato crop to recover part of the nutrients from swine wastewater to reduce the risk of nitrogen (N) and phosphorus (P) losses to the environment. This has proven to be a feasible and promising alternative technology for converting swine wastewater into valueadded product. Liedl et al. (2004) found that liquid effluent of digested poultry litter appeared to function as well as a commercial hydroponic fertilizer for tomatoes after balancing the forms of $\mathrm{N}\left(\mathrm{NO}_{3} / \mathrm{NH}_{4}\right)$ and supplementing with $\mathrm{Ca}\left(\mathrm{NO}_{3}\right)_{2}$ and $\mathrm{MgSO}_{4}$. Abbasi et al. (2004) used fish emulsion in a peat mix to grow radish and cucumber seedlings. The result suggested that fish emulsion had both nutritive value for plant growth as well as disease suppressive properties and thus might be useful for organic or conventional transplant production.

Arbuscular mycorrhizae (AM) are beneficial fungi that colonize roots of almost all vascular plants (Singh and Adholeya, 2002). Linderman and Davis (2001) added Glomus intraradices, an AM fungus, to soil in containers sown with onion (Allium cepa L.) seed, and plants harvested after 10 weeks were more vigorous, when a medium was amended with coconut (Cocos nucifera L.) dust, making up $60 \%$ of the volume, inoculation with $G$. intraradices the development of ornamental flowers was depressed (Linderman and Davis, 2003). Seedling growth of bell pepper (Capsicum annuиm L.) was detrimentally affected by the use of Glomus intraradices (Douds \& Reider, 2003 and Russo, 2006).

Rhizosphere bacteria can be beneficial to plant development (Glick, 2004). Nodule-forming bacteria (Rhizobium sp., now Sinorhizobium sp.) allow for absorption of $\mathrm{N}$ in legumes, and nitrogen fixing bacteria can be associated with roots of nonleguminous crops (Emitiazi, et al., 2003). These bacteria can interact synergistically with mycorrhizal fungi to increase root colonization by both nodulation of roots and amount of nutrients available to plant (Suresh and Bagyaral, 2002). Rhizosphere bacteria have also been reported to reduce the severity of disease in the later stages of the development of cucurbits (KokalisBurelle et al., 2003). In an organic system, addition of beneficial bacteria enhanced tomato yield and quality comparable with a conventional production system (Rippy et al., 2004). Use of Sinorhizobium sp. bacteria appeared to provide a benefit to the development of bell pepper transplant (Russo, 2006).

Egypt. J. Hort. Vol. 42, No.1 (2015) 
Drip irrigation with its ability to small and frequent applications of water has created interest among the farmers because of less water requirement, increasing the production and better quality produce. The production of pepper crop is affected adversely by moisture deficit. The drip irrigation system is observed to be economical and cost effective as compared with conventional surface irrigation (Singh, 2007). Paul et al. (2013) found that, the use of drip irrigation system either alone or in combination with mulching, could increase the capsicum yield up to an extent of $57 \%$ over surface irrigation method with the same quantity of water.

This investigation was designed to determine the effect of organic fertilizers, soil microbial amendments, and water regimes on pepper growth, yield and quality of fruits.

\section{Materials and Methods}

\section{Plant materials and growth conditions}

The experiment was conducted during the two seasons of 2012 and 2013 in a clay loam soil at a private farm near Mansoura City, Egypt (latitude $30^{\circ} 11 / \mathrm{N}$, longitude $28^{\circ} 26 / \mathrm{E}$ and altitude $+7 \mathrm{~m}$ above sea level). Some physical and chemical properties of the experimental soil at the depth of $0-30 \mathrm{~cm}$ were determined according to the standard procedures as described by Page (1982) (Table 1). The local climate is hot and dry during the summer. The average monthly air temperature during the period of study was shown in Table 2. Sweet pepper cv. California Wonder was used in this experiment.

TABLE 1. Chemical analysis of soil before conducting the experiment .

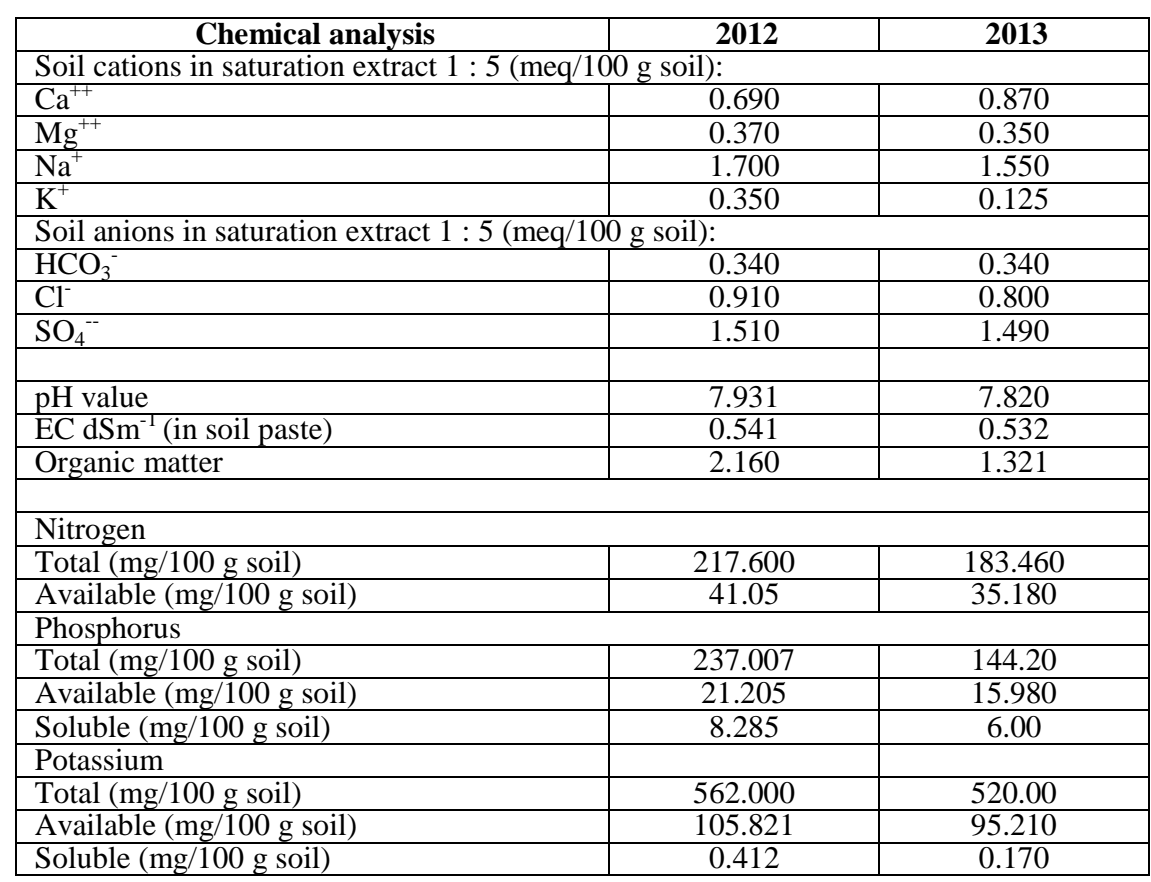


TABLE 2. The monthly mean temperature and relative humidity during crop period in 2012 and 2013 seasons .

\begin{tabular}{|l|c|c|c|c|c|c|c|c|c|c|c|c|}
\hline \multirow{4}{*}{ Months } & \multicolumn{5}{|c|}{ Temperature $^{\circ}$ C } & \multicolumn{5}{c|}{ Relative humidity \% } \\
\cline { 2 - 14 } & \multicolumn{3}{|c|}{2012} & \multicolumn{3}{|c|}{2013} & \multicolumn{3}{|c|}{2012} & \multicolumn{3}{|c|}{2013} \\
\cline { 2 - 14 } & Max. & Min. & Average & Max. & Min. & Average & Max. & Min. & Average & Max. & Min. & Average \\
\hline April & 22 & 12 & 17 & 24 & 12 & 18 & 86 & 47 & 67 & 85 & 48 & 67 \\
\hline May & 28 & 20 & 24 & 28 & 20 & 24 & 85 & 44 & 65 & 86 & 44 & 65 \\
\hline June & 31 & 19 & 25 & 33 & 21 & 27 & 85 & 43 & 64 & 84 & 42 & 63 \\
\hline July & 34 & 20 & 27 & 35 & 21 & 28 & 84 & 41 & 63 & 82 & 42 & 62 \\
\hline
\end{tabular}

Data from Ministry of Agriculture (Agriculture Extension Services)

\section{Experimental design, treatments and crop management}

A split split-plot design based on randomized complete blocks was used. Three irrigation treatments were assigned to the main plots, organic and conventional fertilizers were devoted to the sub-plots and biological amendments were distributed in sub sub-plots. Treatments were replicated three times to make a total of 54 plots. Each experimental sub sub-plot consisted of five ridges each of $0.80 \mathrm{~m}$ wide and $5 \mathrm{~m}$ long with plot area of $20 \mathrm{~m}^{2}$. On March, $1^{\text {st }}$ in both seasons of the study, 45 day old sweet pepper seedlings were transplanted in open field on one side of the ridge at $40 \mathrm{~cm}$ apart.

Irrigation treatments: $60 \%, 80 \%$ and $100 \%$ of evapo-transpirantions (ET).

One meter gap was provided between each main plot to avoid overlap effect of irrigation treatment. Before start of irrigation treatments, crop received equal amount of water immediately after planting which was enough for the proper establishment of plants. The amount of irrigation water applied was measured by a standard $0.2 \mathrm{~m}$ diameter pan $(\mathrm{K}=0.60,0.80$ and 1.00$)$. The water requirement of the crop was computed on daily basis by using the following equation as suggested by Shukla et al. (2001).

\section{$\mathrm{V}=\mathrm{Ep} \times \mathrm{Kp} \times \mathrm{Kc} \times \mathrm{Sp}$ x Sr x Wp}

Where,

$\mathrm{V}=$ Volume of water required (litre / day / plant)

$\mathrm{Ep}=$ Pan evaporation as measured by Class-A pan evaporimeter ( $\mathrm{mm} /$ day $)$

$\mathrm{Kc}=$ Crop co-efficient (co-efficient depends on crop growth stage)

$\mathrm{Kp}=$ Pan co-efficient

$\mathrm{Sp}=$ Plant to plant spacing $(\mathrm{m})$

$\mathrm{Sr}=$ Row to row spacing $(\mathrm{m})$

$\mathrm{Wp}=$ Fractional wetted area, which varies with different growth stage (0.3 to 1.0). The values of pan coefficient and crop coefficients were taken from (Doorenbos and Pruitt, 1977). The water requirement of capsicum crop was estimated on daily basis for all months considered under study.

Egypt. J. Hort. Vol. 42, No.1 (2015) 


\section{Fertilizer treatments}

Recommended doses for mineral fertilizers, nitrogen at a rate of $120 \mathrm{~kg} \mathrm{fed}^{-1}$, phosphate fertilizer at $75 \mathrm{~kg} \mathrm{P}_{2} \mathrm{O}_{5}$ fed $^{-1}$ and potassium fertilizer at rate of $100 \mathrm{~kg} \mathrm{~K}_{2} \mathrm{O} \mathrm{fed}^{-1}$.

The compost was contained $1.8 \%$ available N, $16.4 \%$ organic carbon, E.C. $0.85, \mathrm{C} / \mathrm{N}$ ratio 16.8 and $\mathrm{pH} 6.89$ (average two seasons). Phosphorus and potassium contents in the compost used in this 2 -yr trial were in the range of 0.41 to $0.35 \mathrm{mg} \mathrm{kg}^{-1}$ for $\mathrm{P}$ and 21 to $22 \mathrm{mg} \mathrm{kg}^{-1}$ for K. Compost was prepared according to the method described by Hatem et al., (2008). Compost was completely applied before planting at rowing preparation at 20 ton $\mathrm{fed}^{-1}$.

The organic liquid fertilizer, cow dung (cattle/buffalo) manure, which was used for making the liquid manure (Flickety, 2011 method), was also tested consisting of $\mathrm{N}\left(198 \mathrm{mg} \mathrm{L}^{-1}\right), \mathrm{P}\left(132 \mathrm{mg} \mathrm{L}^{-1}\right), \mathrm{K}\left(300 \mathrm{mg} \mathrm{L}^{-1}\right), \mathrm{Ca}\left(145 \mathrm{mg} \mathrm{L}^{-1}\right)$ and $\mathrm{Mg}\left(25 \mathrm{mg} \mathrm{L}^{-1}\right)$. It was used through drip irrigation at a rate of $20 \mathrm{~m}^{3} \mathrm{fed}^{-1}$. The volume of manure applied with treatment not considers the content of mineral nitrogen because this fraction will be lost by evaporation before incorporation into the soil. Organic nitrogen $\left(2.53 \mathrm{~kg} \mathrm{~m}^{-3}\right)$ was calculated as difference between total nitrogen and $\mathrm{NH}_{3}-\mathrm{N}$.

\section{Biological treatments}

A fresh peat based inoculants of rhizosphere bacteria Sinorhizobium sp. and mycorrhiza AM, obtained from Soils, Water and Environment Res. Inst., Agric. Res. Center, Egypt, was prepared as reported by El-Assiouty and Abo-Sedera (2005) by thoroughly mixing the bacteria cells suspension $(1010$ cells $/ \mathrm{ml})$ with sterilized peat moss at the ratio of 2:1 (v/w) under aseptic conditions. The peat inoculums was used at the rate of $2 \mathrm{~kg} \mathrm{fed}^{-1}$ by mixing with soft dust $(1: 10 \mathrm{w} / \mathrm{w})$ and supplied as soil inoculation into root absorption zone of plants before first irrigation. A mixture of multi-arbuscular mycorrhizal fungi, provided by Prof. Safwat El-Haddad, Plant Pathology Inst., Agric. Res. Center, Giza, Egypt, was used. This mixture consists of equal proportions of spores of Glomus mosseae (Nicol. \& Gerd.) Gerd. \& Trappe, Glomus intraradices Schenck \& Smith, Glomus clarum Nicol. \& Schenck, Gigaspora gigantean (Nicol. \& Gerd.) Gerd. \& Trappe, and Gigaspora margarita (Becker \& Hall) in suspension form at concentration of 106 unit $\mathrm{L}^{-1}$. Mass production of AM inoculum was carried out using the pot culture technique and Sudan grass as a host plant. Spores of the previous formula were inoculated on surface sterilized (10\% sodium hypochlorite for $30 \mathrm{~min}$ ) Sudan grass seeds, which were sown in plastic pots (40 cm diameter) containing twice-sterilized sandy loam soil. A mixture of multiarbuscular mycorrhizal fungi was added into the plots with bacterial inoculants.

The other agricultural practices for growing sweet pepper plants were followed according to the instruction laid down by the Egyptian Ministry of Agriculture, Egypt.

\section{Data and measurements}

Foliage dry weight

At 105 days from transplanting, five plants from each plot were randomly taken and dried at $70^{\circ} \mathrm{C}$ till constant weight for determination of dry weight per plant. 


\section{Yield and some fruit characters}

All harvested fruits from each plot at marketable green ripe stage along the season were used to determine average number of marketable fruits per plant and total yield per feddan. Early yield per feddan was calculated from the first three picking. A representative sample of 10 sweet pepper fruits from each experimental plot were taken from the $4^{\text {th }}$ harvest for determination of fruit quality characters, i.e., fruit flesh thickness, fruit dry matter, total soluble solids (T.S.S.), acidity and vitamin C, according to the methods described by AOAC (1990).

\section{Chemical composition of pepper plant}

Representative samples of sweet pepper plant foliage from each plot at the same time were used to determine $\mathrm{N}, \mathrm{P}$ and $\mathrm{K}$ contents. Total nitrogen was determined according to the methods described by Bremner and Mulvaney (1982), phosphorus was estimated colormetrically according to Olsen and Sommers (1982) and potassium was determined flame photometrically as described by Jackson (1973).

\section{Statistical analysis}

The difference of the treatments was compared using the least significant difference (LSD) test at $P \leq 0.05$ according to Snedecor and Cochran (1989).

\section{Results and Discussion}

The effect of irrigation regimes, organic \& conventional fertilizers and soil microbial amendments on the biomass, fruit number and early \& total yields of sweet pepper.

The effects of the tested factors can be categorized as follows: combined effect of the three factors together, single effect of one factor and combined effect of all the possible interaction between the two factors. The interaction effect among irrigation regimes, organic fertilizers and microbial soil amendments had significant effects on plant foliage dry weight, total fruit number per plot and early and total yields per feddan, in both seasons (Table 3). Irrigation sweet pepper at 80\% ET and the addition of recommended doses of mineral fertilizers plus microbial inoculants (Rhizosphere bacteria Sinorhizobium sp. and mycorrhiza AM) exhibited significant positive effects on yield parameters compared with other treatments (Table 3).

When organic and biofertilizers were kept constant, irrigation regimes had a significant effect on biomass and yield parameters (Table 3). Irrigation sweet pepper at $80 \%$ ET level recorded the highest significant values of growth and yield studied parameters in comparison with both irrigation treatments. This result corroborated the findings of Paul et al. (2013). In drip irrigation system, water is applied at a low rate for a longer period at frequent intervals near the plant root zone through lower pressure delivery system, which increases the availability of nutrients near the root zone with a reduction in leaching losses. More nutrient availability, especially near the root zone might have increased the translocation of photosynthesis to storage organ of capsicum resulting in an increased in the weight of capsicum (Sankar et al., 2008).

Egypt. J. Hort. Vol. 42, No.1 (2015) 
EFFECT OF ORGANIC FERTILIZERS, IRRIGATION REGIMES ...

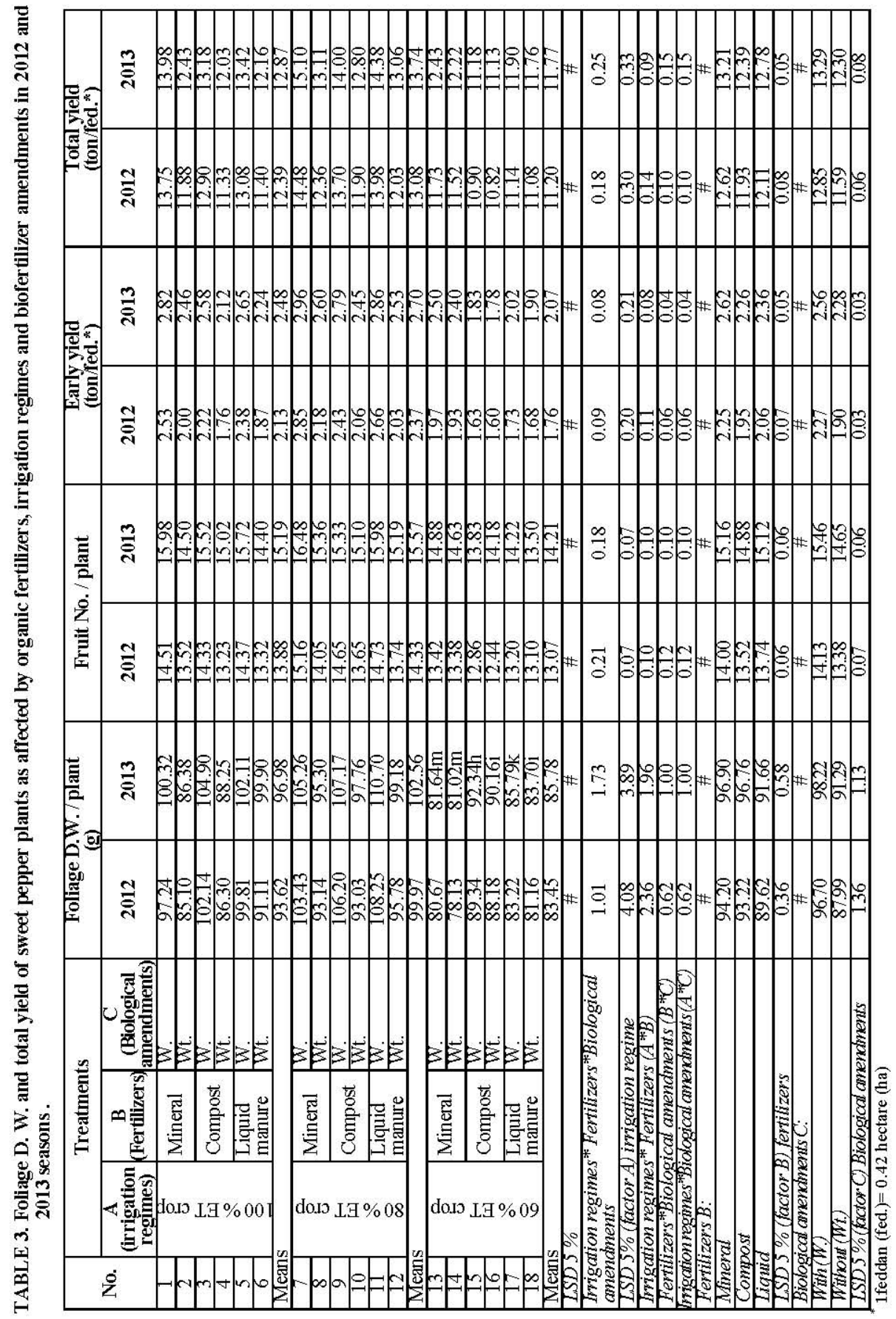

Egypt. J. Hort. Vol. 42, No.1 (2015) 
Recommended doses of mineral fertilizers or application of soil amendments had significant effects in all studied parameters as compared to other treatments (Table 3).

The combined effect of all the possible interaction between the two factors had significant effects on most studied parameters (Table 3 ).

Studies comparing yield of organically and conventionally grown crops often give inconsistent results. Some studies have found yield to be lower in organic than in conventional treatments in both field and greenhouse crops (Heeb et al., 2005, 2006, Mäder et al., 2002). On the other hand, no significant differences in total marketable yield of sweet pepper (Del Amor, 2007) and tomato (Rippy et al., 2004) have been observed when comparing organic and mineral fertilization, although in the study with tomato, the harvest duration was relatively short. Herencia et al. (2007) also found that crop yield was not statistically different between organic and mineral fertilizer treatments. Our results make sure with previous studies.

The use of bacteria appeared to increase plant dry weight and total yield per feddan. Even if bacteria do not infect plant tissues, they are capable of changing the rhizosphere in a way that could contribute to an environment beneficial to plant development (Dobbelaere et al., 2003 and Russo, 2006). Use of AM appeared to improve plant growth and productivity of sweet pepper. Mycorrhiza fungi can affect the environment around roots by physical and biological means (Suresh and Bagyaral. 2002).

The effect of irrigation regimes, organic \& conventional fertilizers and soil microbial amendments on the fruit chemical composition and fruit dry matter of sweet pepper.

Nitrogen, phosphorus and potassium concentrations and percentage of fruit dry matter were significantly affected by main effects and interactions (Table 4).

Amendments with bacteria and fungi (Sinorhizobium sp. and mycorrhiza AM), fertilizers (liquid manure) and irrigation regime (80\% ET) had significant effects of fruit element composition $(\mathrm{N}, \mathrm{P}$ and $\mathrm{K}$ ) and fruit dry matter, in comparison with other treatments, in both seasons (Table 4).

Irrigation of sweet pepper at $80 \%$ of ET had a significant effect on mineral composition and fruit dry matter (Table 4$)$.

Application of compost manure or mineral fertilizer or microbial amendments had increased values of NPK contents and fruit DM (Table 4).

The interaction of irrigation regime $\mathrm{x}$ organic \& conventional fertilizers, the amendment $\mathrm{x}$ fertilizer and the amendment $\mathrm{x}$ irrigation regime interaction had significant effects on N, P and K fruit contents and fruit DM, in both seasons (Table 4).

Egypt. J. Hort. Vol. 42, No.1 (2015) 
Based on the results, drip irrigation treatment ( $80 \%$ of ET) increased yield by $4.67 \%$ and $6.22 \%$, in both seasons, respectively, as compared to irrigation at $80 \%$ of ET. This result is in close agreement with the findings of Tiwari et al. (1998) on okra and Paul et al. (2013) on pepper plants. The beneficial effect of NPK characters advantage better water-use-efficiency through drip irrigation is attributed to the continuous supply of water in required quantity at right time without flooding to cause hypoxia. Therefore, the roots remain well aerated (Lingaiah et al., 2005).

Because organic production systems depend on mineralization of nutrients from organic substrates, they are more dependent on soil biological activity than are conventional production systems in which plant-available forms of $\mathrm{N}$ and $\mathrm{P}$ are supplied in the form of soluble chemical fertilizers. Consequently, we hypothesized that mineralization of macronutrients would be the primary factor limiting yields in organic treatments and that measurements of gross biological activity, which are indicative of gross nutrient mineralization (Table 4), would be correlated with yields across the range of organic treatments (Table 3). These findings are in line with those reported by Zhai (2009) on organic tomatoes.

Biological control using the arbuscular mycorrhizal fungi (AM) has special significance being an ecofriendly and cost effective strategy for disease management, in addition to the positive effects on the plant growth and nutrition. Several researchers have studied the application of Glomus mosseae, G. intraradices, G. clarum, Gigaspora gigantea, and G. margarita on various crops. It was found that they have an important role in the enhancement of plant growth, nutrition, water relations and resistance to plant diseases caused by several pathogens on different host species (Leta and Selvaraj, 2013, Sennoi et al., 2013). In addition, Russo et al. (2006) reported that addition of Sinorhizobium bacteria provided a benefit to transplant growth of pepper and thus mineral status of foliage.

The effect of irrigation regimes, organic \& conventional fertilizers and soil microbial amendments on the fruit quality parameters of sweet pepper.

Treated sweet pepper plants with organic fertilizers (liquid manure), and biological amendments (Sinorhizobium sp. and mycorrhiza AM) under $80 \%$ of evapo-transpiration had significant effects on fruit quality parameters, expressed as, fruit flesh thickness, vitamin $\mathrm{C}$, total soluble soils and acidity, in comparison with other treatments, in both seasons (Table 5).

When irrigated sweet pepper at $80 \%$ ET level, fruit quality increased significantly as compared to other both irrigation levels (100 and 60\% ET), in both seasons (Table 5).

Application of compost manure or microbial amendments had significant increase of quality parameters (Table 5).

As for bilateral interactions between different factors, it had significant effect of all fruit quality parameters (Table 5). 


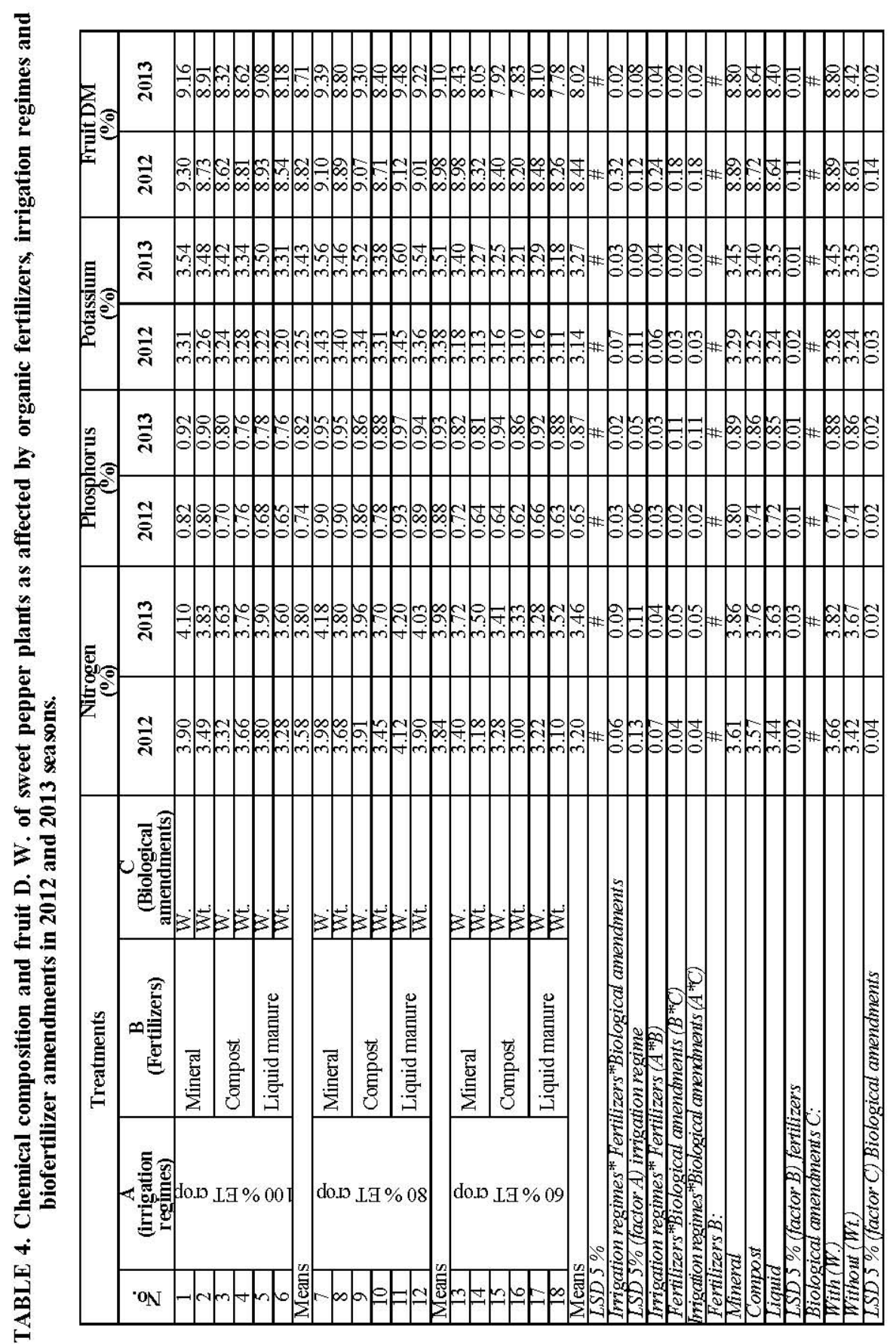

Egypt. J. Hort. Vol. 42, No.1 (2015) 
EFFECT OF ORGANIC FERTILIZERS, IRRIGATION REGIMES ...

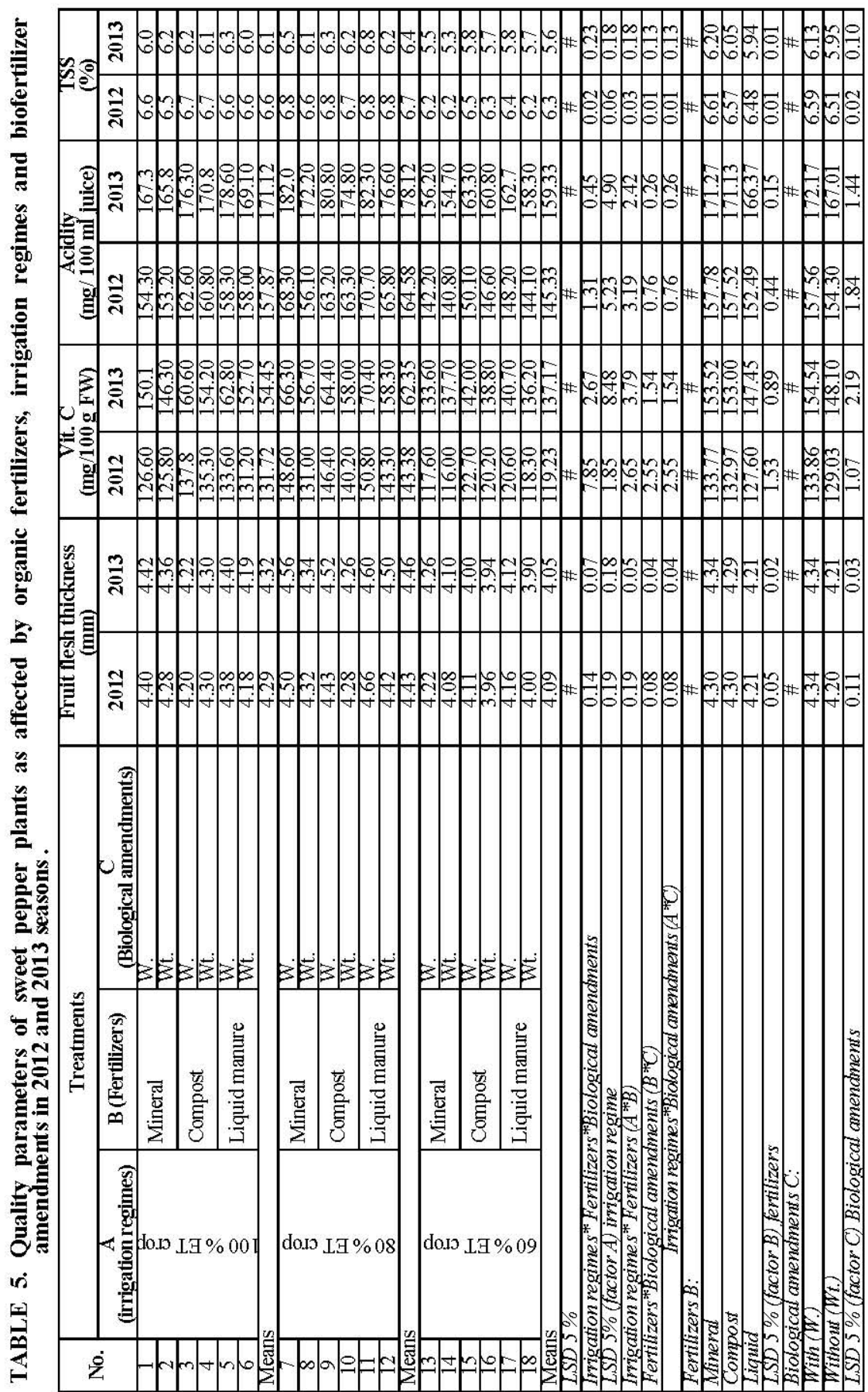

Egypt. J. Hort. Vol. 42, No.1 (2015) 
Our results are in agreement with those reported by Jones et al. (2000), they stated that water deficit during this period would have the greatest negative impact on yield and quality. Optimum soil water content during flowering was at $80 \%$ of the available water and that either higher or lower water content resulted in suboptimal fruit yields. Soil water should be maintained between 75 and $80 \%$ of field capacity (Jones et al., 2000). The higher pepper marketable yield and quality recorded under mild stress conditions, has been previously reported by several authors (Karam et al., 2009).

Concerning the effect of bio-organic treatment, the result may be due to the role of organic and bio-fertilizer on increasing the availability of nitrogen for plant absorption which in turn increases the vegetative growth and increasing yield as well as improving quality. Also, the superiority of the bio fertilizer may be due to the release of the fixed nitrogen, hence increasing the concentration and availability of this element in root zone. Nitrogen also enhances protein synthesis, division and enlargement of cells as well as stimulates photosynthesis processes. This is in agreement with results reported by (Reyes et al., 2008, Ghoname and Shafeek, 2005) on sweet pepper plants.

\section{References}

Abbasi, P.A., Conn, K.L. and Lazarovits, G. (2004) Suppression of Rhizoctonia and Pythium damping-off of radish and cucumber seedlings by addition of fish emulsion to peat mix or soil. Can. J. Plant Pathol., 26,177-187.

A.O.A.C. (1990) Official Methods of Analysis of the Association of Official Edition, Washington, D.C.

Bremner, J.M. and Mulvaney, C.S. (1982) Total nitrogen. In: Methods of Soil Analysis, Part 2, Page, A.L., R.H. Miller and D. R. Keeney (Ed.) Amer. Soc. Agron. Madison, W. I. USA, pp.595- 624.

Celik, I., Ortas, I. and Kilic, S. (2004) Effect of compost, mycorrhiza, manure and fertilizer on some physical properties of a Chromoxerert soil. Soil Till. Res., 78, 59-67.

Cheng, J., Shearin, T.E., Peet, M.M. and Willits, D.H. (2004) Utilization of treated swine wastewater for greenhouse tomato production. Water Sci. Technol., 50, 77-82.

Chong, C. (2005) Experiences with wastes and composts in nursery substrates. HortTechnol., 15, 739-747.

Chong, C. and Purvis, F.M. (2004) Nursery crop response to substrates amended with raw mill sludge, composted paper mill sludge and composted municipal waste. Can. J. Plant Sci., 84, 1127-1134.

Del Amor, F.M. (2007) Yield and fruit quality response of sweet pepper to organic and mineral fertilization. Renew. Agric. Food Sys., 22, 233-238.

Egypt. J. Hort. Vol. 42, No.1 (2015) 
Dobbelaere, S., Vanderleyden, J. and Okon, Y. (2003) Plant growth promoting effects of diazotrophs in the rhizosphere. Crit, Rev. Plant Sci., 22, 107-149.

Doorenbos, J. and Pruitt, W.O. (1977) Guidelines for predicting crop water requirements. Irrigation and Drainage Paper 24, FAO, Rome.

Douds, Jr. D.D. and Reider, C. (2003) Inoculation with mycorrhizal fungi increases the yield of green peppers in a high P soil. Biol. Agric. Hort., 21, 91-102.

El-Assiouty, F.M.M. and Abo-Sedera, S.A. (2005) Effect of bio and chemical fertilizers on seed production and quality of spinach (Spinacia oleracea L.). J. Agric. Biol., 7(6), 947-952.

Emitiazi, G., Etemadifar, Z. and Tavassoli, M. (2003) A novel nitrogen-fixing bacteria associated with root of corn is a candidate for production of single cell protein. Biomass Bioenergy, 25, 423-426.

Flickety, M. (2011) How to make homemade liquid manure from cow pats. Last (Ed.), July 2, 2011. Retrieved form: http://www.wikihow.com/Make-Liquid-Manure-fromCow-Pats. (Accessed on: Oct.13, 2011).

Ghoname, A. and Shafeek, M.R. (2005) Growth and productivity of sweet pepper (Capsicum annum L.) grown in plastic house as affected by organic, mineral and bioN-fertilisers, J. Agron., 4 (4), 369-372.

Glick, B.R. (2004) Change in plant growth and development by rhizosphere bacteria that modify plant ethylene level. Acta Hort., 631, 265-273.

Hatem, M.H., Ibrahim, W.M., Kamel, O.M. and Attia, R.M. (2008) Production of compost from rice straw under prototype condition. The $15^{\text {th }}$ Annual Conference of the Misr Soc. Agric. Eng., 12-13 March., 579- 590.

Heeb, A., Lundegårdh, B., Ericsson, T. and Savage, G.P. (2005) Effects of nitrate-, ammonium-, and organic-nitrogen-based fertilizers on growth and yield of tomatoes. J. Plant Nutr. Soil Sci., 168,123-129.

Heeb, A., Lundegårdh, B., Savage, G. and Ericsson, T. (2006) Impact of organic and inorganic fertilizers on yield, taste, and nutritional quality of tomatoes. J. Plant Nutr. Soil Sci., 169, 535-541.

Herencia, J.F., Ruiz-Porras, J.C., Melero, S., Garcia-Galavis, P.A., Morillo, E. and Maqueda, C. (2007) Comparison between organic and mineral fertilization for soil fertility levels, crop macronutrient concentrations, and yield. Agron. J., 99, 973-983.

Jackson, M.L. (1973) "Soil Chemical Analysis" Prentic-Hall, India, pp. 144-197.

Jones T., Bessin, R., Strang, J., Rowell, B. and Spalding, D. (2000) Kentucky pepper integrated crop management. Coop. Exten. Service, Univ. Kentucky, Collage Agric., p. 38.

Karam, F., Masaad, R., Bachour, R., Rhayem, C. and Rouphael, Y. (2009) Water and radiation use efficiencies in drip-irrigated pepper (Capsicum annuum L.): response to full and deficit irrigation regimes. Eur. J. Hort. Sci., 74 (2), 79-85. 
Kokalis-Burelle, N., Vavrina, C.S., Reddy, M.S. and Klopper, J.W. (2003) Amendment of musk melon and watermelon transplant media with plant growth-promoting rhizobacteria: Effects on seedling quality, disease and nematode resistance. Hort. Technology, 13, 476-482.

Lee, J.J., Parkl, R.D., Kim, Y.W., Shim, J.H., Chae, D.H., Rim, Y.S., Sohn, B.K., Kim, T.H. and Kim, K.Y. (2004) Effect of food waste compost on microbial population, soil enzyme activity and lettuce growth. Bioresour. Technol., 93, 21-28.

Leta, A. and Selvaraj, T. (2013) Evaluation of arbuscular mycorrhizal fungi and Trichoderma species for the control of onion white rot (Sclerotium cepivorum Berk). J. Plant Pathol. Microbiol., 4 (1), 1-6.

Liedl, B. E., M. Cummins, A. Young, M. L.Williams and J. M. Chatfield (2004). Liquid effluent from poultry waste bioremediation as a potential nutrient source for hydroponic tomato production. Acta Hort., 659, 647-652.

Linderman, R. G. and E. A. Davis (2001). Vascular arbuscular mycorrhiza and plant growth responses to soil amendment with composted grape pomace or its water extract. Hort Technology, 11, 446-450.

Linderman, R.G. and Davis, E.A. (2003) Arbuscular mycorrhiza and growth responses of several ornamental plants grown in soillness peat-based medium amended with coconut dust (coir). HortTechnology, 13, 482-487.

Lingaiah, D., Katti, G.S. and Mohammad, S. (2005) Influence of drip irrigation on crop growth, yield and water use efficiency in cabbage. International J. Agric. Sci., 1 (1), 110-111.

Mäder, P., Fließbach, A., Dubois, D., Gunst, L., Fried, P. and Niggli, U. (2002) Soil fertility and biodiversity in organic farming. Sci., 296, 1694-1697.

Marinari, S., Masciandaro, G., Ceccanti, B. and Grego, S. (2000) Influence of organic and mineral fertilisers on soil biological and physical properties. Bioresour. Technol., 72, 9-17.

Marti'nez, F., Pe'rez, S., Carmona, E., Ordova's J. and Avile's, M. (2005) Effect of different soilless growing systems on biological properties of growth media in strawberry. Acta Hort., 697, 417-423.

azuela, P., Salas, M.C. and Urrestarazu, M. (2005) Vegetable waste compost as substrate for melon. Commun. Soil Sci. Plant Anal., 36, 1557-1572.

Olsen, S.R. and Sommers, L.E. (1982) Phosphorus. In: Methods of Soil Analysis Part 2, Page, A.L., Miller, R.H. and Keeney, D.R. (Ed.), pp. 403-430, Amer. Soc. Agron. Madison, W.I., U.S.A.

Paul, J.C., Mishra, J.N., Pradhan, P.L. and Panigrahi, B. (2013) Effect of drip and surface irrigation on yield, water use-efficiency and economics of capsicum (Capsicum annum L.) grown under mulch and non mulch conditions in eastern coastal India. European J. Sus. Develop., 2 (1), 99-108.

Egypt. J. Hort. Vol. 42, No.1 (2015) 
Page, A.L. (1982) "Methods of Soil Analysis", $2^{\text {nd }}$ ed., Part 1, Soil Sci. Soc. Amer., Madison, Wisc., USA.

Reyes, I., Alvarez, L., El-Ayoubi, H. and Valery, A. (2008) Selection and evaluation of growth promoting rhizobacteria on pepper and maize. Bioagro., 20 (1), 37-48. 28.

Rippy, J.F.M., Peet, M.M., Louws, F.J., Nelson, P.V., Orr, D.B., and Sorensen, K.A. (2004) Plant development and harvest yield of greenhouse tomato in six organic growing systems. HortScience, 39, 223-229.

Russo, V.M. (2006) Biological amendment, fertilizer rate, and irrigation frequency for organic bell pepper transplant production. HortScience, 41 (60), 1402-1407.

Sankar, V., Lawande, K.E. and Tripathy, P.C. (2008) Effect of micro irrigation on growth, yield and water-use-efficiency of onion (Allium cepa) under western Maharashtra conditions. Indian J. Agr. Sci., 78 (7), 584-588.

Sennoi, R., Singkham, N., Jogloy, S., Boonlue, S., Saksirirat, W., Kesmala, T. and Patanothai, A. (2013) Biological control of southern stem rot caused by Sclerotium rolfsii using Trichoderma harzianum and arbuscular mycorrhizal fungi on Jerusalem artichoke (Helianthus tuberosus L.). Crop Protec., 54 148-153.

Shukla, K.N., Singh, P.K. and Singh, K.K. (2001) Crop water requirement under drip irrigation. Plasticulture Development Centre, GBPUAT, Pantnagar.

Singh, A. (2007) Economic feasibility of drip irrigated tomato crop under rain fed condition. Agricultural Engineering Today, ISAE, 31(3\&4), 1-5.

Singh, R. and Adholeya, A. (2002) Plant and fungal responses to colonization, In: Arbuscular mycorrhizae: Interactions in plants, rhizosphere, and soils, A.K. Sharma and B.N. Johri (Ed.) pp. 213-230, Science Publishers, Enfield. N. H.

Snedecor, G.W. and Cochran, W.G. (1989) "Statistical Methods", $8^{\text {th }}$ ed. $2^{\text {nd }}$ Printing. Iowa State Univ. Press, Ames, USA.

Suresh, C.K. and D.J. Bagyaral (2002) Mycorrhiza-microbe interactions: Effect of rhizosphere, In: Arbuscular mycorrhiza interactions in plants, rhizosphere and soils, A.K. Sharma and B.N. Johri (Ed.) pp. 7-28, Science Publishers, Enfield, N. H.

Tiwari, K.N., Mal, P.K., Singh, R.K. and Chattopadhya, A. (1998) Response of okra to drip irrigation under mulch and non-mulch conditions. Agricultural Water Management, 38, 91-102.

Zhai, Z. (2009) Organic fertilizers for greenhouse tomatoes: productivity and substrate microbiology. HortScience, 44 (3), 800-809.

(Received 1/3/2015;

accepted 20/5/2015) 


\section{تأثير معاملات التسميد العضوي وأنظمة الري والتسميد الحيوي على النمو والإنتاجية في الفلفل الحلو}

$$
\text { أقسام بحوث محمود السعيد ـ معهد بحوث البساتين - مركز البحوث الزر اعية ـ القاهرة - }
$$

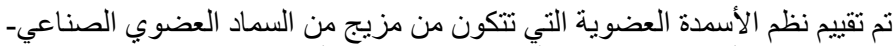

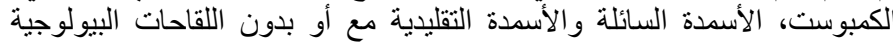

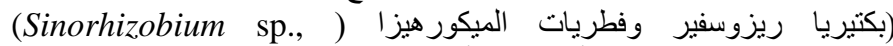
mycorrhiza AM

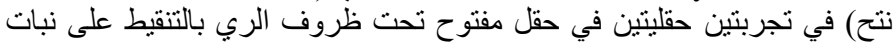

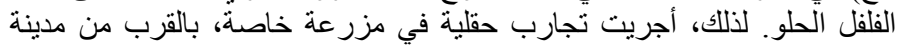

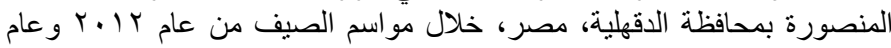

$$
\text { r. Ir }
$$

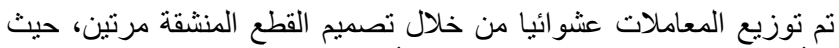

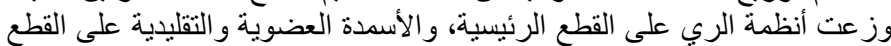
المنشقة واللقاحات ألميكروبية على الفي القطع تحت الثقية.

أدي التفاعل المشترك باستخدام نظام الري عند ــ من البخر نتح والكمية

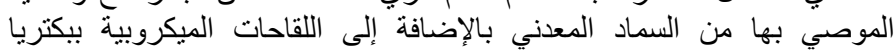

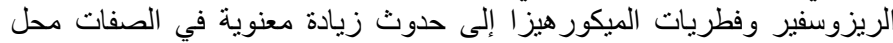

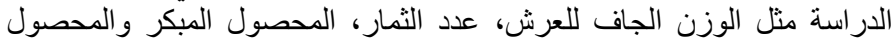

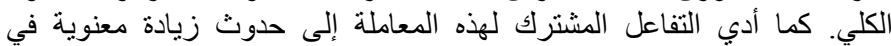

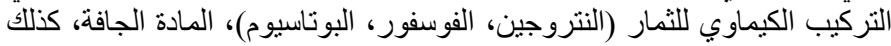

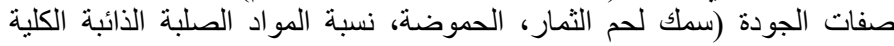

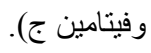

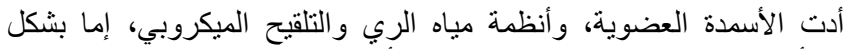

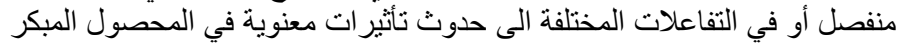
و المحصول التكلي، عدد الثمار للنبات، وزيادة سمك لحم الثمار ومعائير الجير الجودة. 